\title{
Interactions between whale sharks, Rhincodon typus Smith, 1928 (Orectolobiformes, Rhincodontidae), and Brazilian fisheries: The need for effective conservation measures
}

\author{
Márcio Luiz Vargas Barbosa-Filho ${ }^{\mathrm{a}, *}$, Davi Castro Tavares ${ }^{\mathrm{b}}$, Salvatore Siciliano ${ }^{\mathrm{c}}$, \\ Jailson Fulgencio de Moura ${ }^{\mathrm{d}}$, Eraldo Medeiros Costa-Neto ${ }^{\mathrm{e}}$, Fabio dos Santos Motta ${ }^{\mathrm{f}, \mathrm{g}}$, \\ Christine Del Vechio Koike ${ }^{a}$ \\ a Departamento de Ciências Biológicas (DCB), Programa de Pós-graduação em Zoologia, Universidade Estadual de Santa Cruz, Rodovia Jorge Amado, Km 16, \\ Salobrinho, 45662-900 Ilhéus, BA, Brazil \\ ${ }^{\mathrm{b}}$ Universidade Estadual do Norte Fluminense Darcy Ribeiro - UENF, Av. Alberto Lamego, 2000, Parque Califórnia, 28013-602 Campos dos Goytacazes, RJ, \\ Brazil \\ 'Instituto Oswaldo Cruz/FIOCRUZ, Pavilhão Mourisco - sala 122, Av. Brasil, 4.365 - Manguinhos, 21040-360 Rio de Janeiro, RJ, Brazil \\ ${ }^{\mathrm{d}}$ Leibniz Center for Tropical Marine Ecology - ZMT, Systems Ecology Group, Fahrenheitstraße 6, 28359 Bremen, Germany \\ e Departamento de Ciências Biológicas, Universidade Estadual de Feira de Santana, Avenida Transnordestina S/N, Novo Horizonte, 44036-900 Feira de \\ Santana, BA, Brazil \\ ${ }_{\mathrm{f}}^{\mathrm{f}}$ Laboratório de Ecologia e Conservação Marinha, Instituto do Mar, Universidade Federal de São Paulo, Santos, Brazil \\ ${ }^{\mathrm{g}}$ Laboratório de Pesquisa de Elasmobrânquios, Universidade Estadual Paulista, São Vicente, Brazil
}

\section{A R T I C L E I N F O}

\section{Article history:}

Received 23 March 2016

Received in revised form

11 August 2016

Accepted 14 August 2016

Available online 29 August 2016

Keywords:

Artisanal fisheries

Endangered species

Collaborative monitoring program

\begin{abstract}
A B S T R A C T
This study reports three interaction events between the whale shark (Rhincodon typus) and fisheries in Brazilian waters. Two events were described as incidental captures in a gillnet fishery on the northern coast of Rio de Janeiro State, in southeastern Brazil. The last event took place at the Royal Charlotte Oceanic Bank (RCOB), in the southern region of Bahia State, where five fishermen filmed their interaction with a juvenile specimen. For one of the incidental captures, the fish was landed and consumed by locals, and for the other, the shark was released. In the RCOB, the fishermen touched the whale shark with their hands, wooden sticks and even rode on it. In addition, 74 interviews were conducted with fishermen from Bahia about sightings and possible interactions with R. typus. According to statements made by the fishermen, although not frequent, the conduct reported for the RCOB occasionally takes place in the region. Evaluating information of this nature is important to support government plans that regulate fishing activities in order to reduce incidental captures and the harassment of whale sharks. Encouraging the participation of fishermen in a collaborative monitoring program for $R$. typus may be a good way to better understand the threats to the species at a reduced cost, particularly for developing countries, such as Brazil.
\end{abstract}

(c) 2016 Elsevier Ltd. All rights reserved.

\section{Introduction}

The whale shark, Rhincodon typus (Smith, 1828), is the largest living elasmobranch in the world, reaching $20 \mathrm{~m}$ long, and has a cosmopolitan distribution in all tropical and warm temperate seas

\footnotetext{
* Corresponding author.

E-mail addresses: titobiomar@hotmail.com (M.L.V. Barbosa-Filho), wetlandbirdsbrazil@gmail.com (D.C. Tavares), gemmlagos@gmail.com (S. Siciliano), jailsonfm@gmail.com (J.F.d. Moura), eraldont@hotmail.com (E.M. Costa-Neto), limbatus@gmail.com (F.d.S. Motta), chris_oceano@yahoo.com.br (C. Del Vechio Koike).
}

from $30^{\circ} \mathrm{N}$ to $30^{\circ} \mathrm{S}$ [1]. This species is unmistakable because of its broad head and mouth with a truncated snout, and clear circular spots disposed longitudinally over its entire body [2]. It is a filter feeder and consumes a wide variety of planktonic and nektonic organisms, including small crustaceans (copepods, sergestids and euphausids), fish larvae and small schooling fish [3,4] that are generally caught near the surface [5]. In the presence of humans, $R$. typus often becomes curious [6], and the attraction of humans to this species is often reciprocated. Its large size and non-threatening behavior result in reliable and profitable tourism activities at feeding aggregation sites, making $R$. typus one of the top three most popular species of sharks in the ecotourism industry [7]. 
However, injuries and harassment associated with ecotourism can harm and disrupt the natural behavior of this shark $[3,6]$, which has led to the development of codes of conduct and regulations to protect whale sharks from being disturbed [8]. For example, in the Ningaloo Reef of NW Australia, changes in feeding and swimming behavior in the presence of humans have been observed since the enforcement of the "Tourist compliance to a Code of Conduct for Whale Sharks" [9]. In recent years, this type of intervention has become even more urgent, due to numerous videos published in the media worldwide that show humans touching and even riding these sharks. For this reason, it is crucial to develop comparative studies that analyze the behavior of $R$. typus in the presence and in the absence of harassment $[6,9]$ in order to assess the magnitude of the impact of these interactions.

Globally, the whale shark is considered endangered [10], particularly due to being targeted in fisheries and because of incidental catches in nets [11,12]. For example, Akhilesh et al. [13] reported capture by gillnets as a major cause of $R$. typus landings in coastal India. Furthermore, the trade of liver oil and fins has been an incentive to catch these sharks and is recognized as the main conservation challenge for this species [14]. Also, the pressure of harpoon fisheries for whale sharks in Southeast Asia is well documented and considered a great threat to the species $[15,16]$. Currently, the whale shark is the marine species that has the highest potential value in international luxury markets, putting it at extreme risk of extinction [17].

In Brazil, considering the 3.5 million $\mathrm{km}^{2}$ of exclusive economic zone (EEZ), reports of whale sharks are scarce, comprising only 119 observations $[18,19]$. The species seems to occur throughout the coast and around oceanic islands, but to date, little data is available on its biology and ecology in the region [20,21]. Fishing, transportation, storing and management of $R$. typus are prohibited in Brazil [22]. Consequently, environmental authorities have the challenge of controlling by-catch of whale shark while not interfering with legal fishing of non-threatened species.

In this context, information about whale shark mortality will help in the assessment of human related impacts on the species at a regional level. The aim of the present study was to evaluate the impact of lethal and non-lethal interactions between whale sharks and commercial fisheries in different regions of coastal Brazil.

\section{Materials and methods}

Information about whale shark fisheries was recorded along the coast of the municipalities of Carapebus $\left(22^{\circ} 15^{\prime} \mathrm{S}, 41^{\circ} 37^{\prime} \mathrm{W}\right)$ and Quissamã ( $\left.22^{\circ} 10^{\prime} \mathrm{S}, 41^{\circ} 23^{\prime} \mathrm{W}\right)$, in northern Rio de Janeiro State, southeastern Brazil, and on the Royal Charlotte Oceanic Bank (RCOB) $\left(15^{\circ} 39^{\prime} 33^{\prime \prime} \mathrm{S}, 37^{\circ} 58^{\prime} 21^{\prime \prime} \mathrm{W} / 16^{\circ} 16^{\prime} 23^{\prime \prime} \mathrm{S}, 37^{\circ} 56^{\prime} 47^{\prime \prime} \mathrm{W}\right)$, in southern Bahia State, northeastern Brazil. The first region is under influence of the Brazil current and the Cabo Frio upwelling system, where highly productive deep waters flow along the coast due to the predominance of north/northeast winds [23]. The RCOB is part of the northern boundary of the Abrolhos region, an area with the highest marine biodiversity in a coral reef complex in the South Atlantic Ocean [24]. It is a shallow platform of $8.400 \mathrm{~km}^{2}$, with an irregular surface [25], and has rectangular geomorphological formations where the continental shelf extends $100 \mathrm{~km}$ east-west and $50 \mathrm{~km}$ north-south [26]. The study area and where each event occurred are outlined in Fig. 1.

A database including information on the occurrence of $R$. typus along the coast of Rio de Janeiro was created using records gathered from the literature, newspapers, media reports, and our own data of two incidental captures obtained directly from fishermen and locals from Rio de Janeiro (mainly Quissamã) between February 1983 and October 2012. The lengths of the individuals were visually estimated or obtained using a tape measure.

Data on the interaction at the RCOB were collected from a 09 min $18 \mathrm{~s}$ video recorded by one of five fishermen onboard a vessel, as well as from semi-structured interviews with all crew members. Additionally, data from 74 interviews with fishermen from Ilhéus, Una and Canavieiras, whom were shown a whale shark photograph, were added to the database. The interview questions were asked in order to investigate the awareness and attitudes of the respondents concerning the close sightings of whale sharks and their possible interactions with this elasmobranch species. Before each interview, respondents were assured of their anonymity.

\section{Results}

On 02 February 2001, a whale shark (10.8 m long) was captured in the gillnets of an artisanal fishery approximately seven nautical miles off the coast of Carapebus, in northern Rio de Janeiro State. The shark was dragged by three boats and landed by fishermen in Quissamã (an adjacent municipality). In fact, the shark was towed and landed due to the suspected value of its fins; however, neither the whale shark nor its fins had high commercial value at the time and the specimen was consumed by locals (Fig. 2A).

In the second event off Rio de Janeiro, on 19 July 2012, a specimen of $R$. typus (approximately eight meters long) was captured by two boats operating gillnets around four nautical miles off the coast of Quissamã (Fig. 2B). In this particular case, fishermen dove and cut their gillnets to release the fish, showing a lack of interest in its commercial value. Both captures were carried out by the gillnet fishery fleet of Barra do Furado, from Quissamã. The gillnets (70 $\mathrm{mm}$ ) used during the incidental captures of the specimens were about three kilometers long.

A total of 18 individuals were reported along the coast of Rio de Janeiro State between February 1983 and July 2012, including records from the present study and the list provided by Gomes et al. [27]. The records were distributed throughout the seasons of the year (Table 1), occurring every month except October and December.

The interaction in Bahia State took place in October 2011 between 03:00 pm and 05:00 pm, while the sea was calm. The informants were fishing with hooks and lines, 17 miles offshore and $85 \mathrm{~m}$ deep, in the RCOB. They reported that the shark was foraging on small fish and shrimp associated with the hull of the vessel, demonstrating knowledge about the diet of the species. In the video, the shark's mouth is stained with the boat's paint, which indicates a potential risk related to the interaction of these animals with boats.

Fishing activity was completely interrupted by the crew while the video was being recorded. The fishermen were highly excited, splashing the water, touching the animal and even poking it with a wooden stick (Fig. 3) to see the shark's reaction. On several occasions, the shark swam towards the fishermen when a hand or an object was in the water.

Three out of five fishermen stepped on and even rode the animal during the episode. No awareness reaction of fishermen was observed regarding risk of injury during the interaction. According to the fishermen, they had seen people swimming near whale sharks in television shows or movies and this had encouraged them to interact closely with the fish.

In the remaining interviews, three fishermen affirmed to have ridden a whale shark and the same number reported seeing fellow fishermen riding the species at least once. In addition, twelve fishermen stated they had touched whale sharks with a hand and / or other objects (pieces of wood, lead sinkers). Although not commonplace, it can be seen that cases of whale shark harassment 


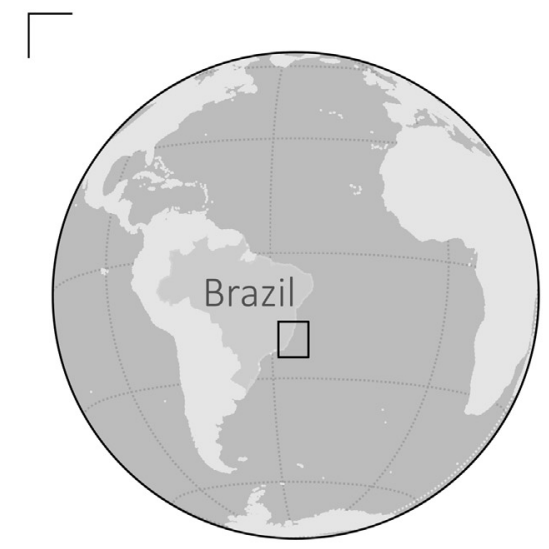

MAP LEGEND

Whale Shark Occurence

- Sightings $\Delta$ Strandings Bycatch

Bathymetry

$\square<50 \mathrm{~m} \quad \square>50<200 \quad \square>200$

\section{States}

RJ - Rio de Janeiro; BA - Bahia

ES - Espírito Santo; $\quad$ MG - Minas Gerais

Interview Location

RCOB - Royal Charlotte Oceanic Bank
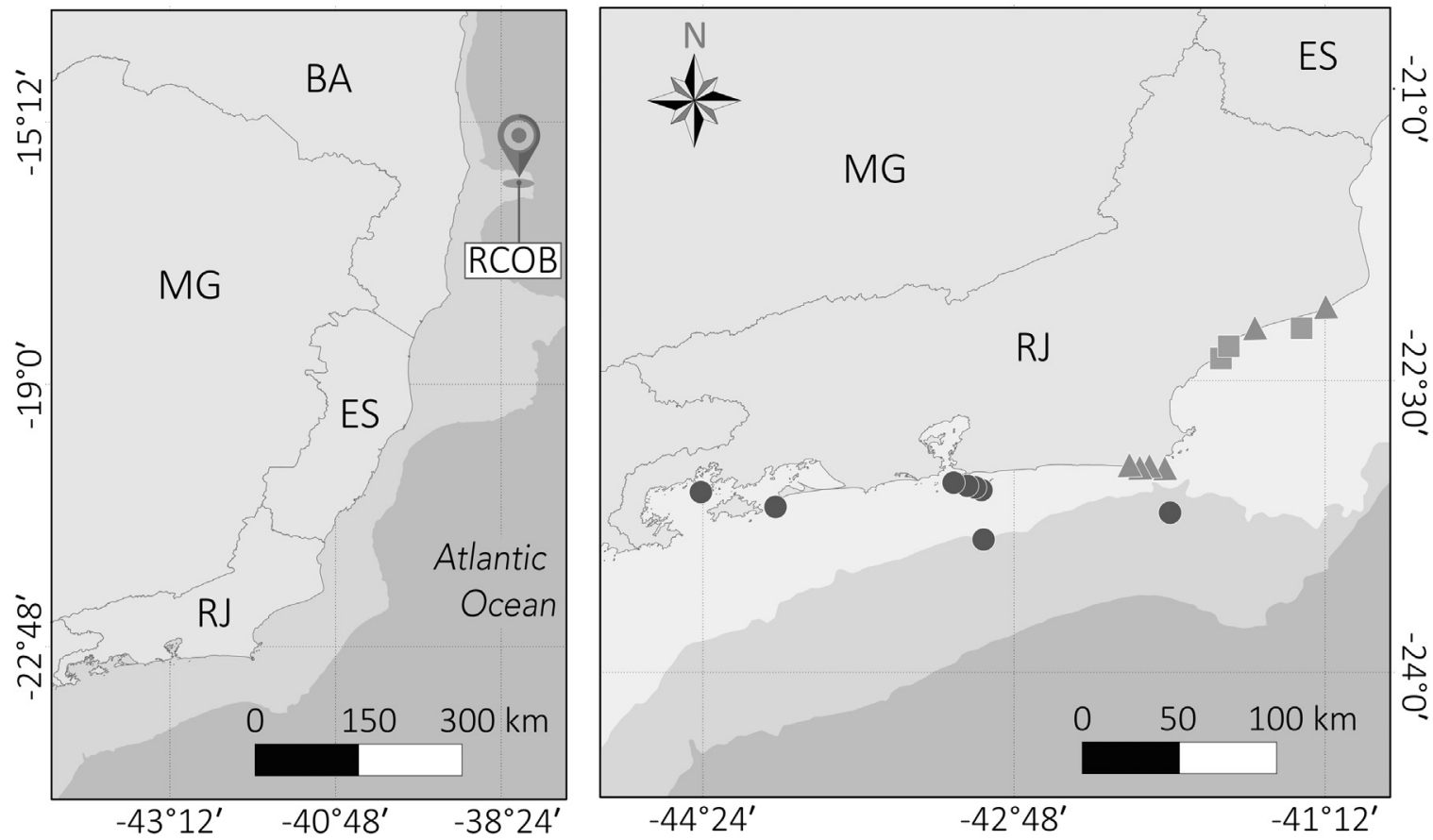

Fig. 1. Brazilian areas where the interactions occurred.
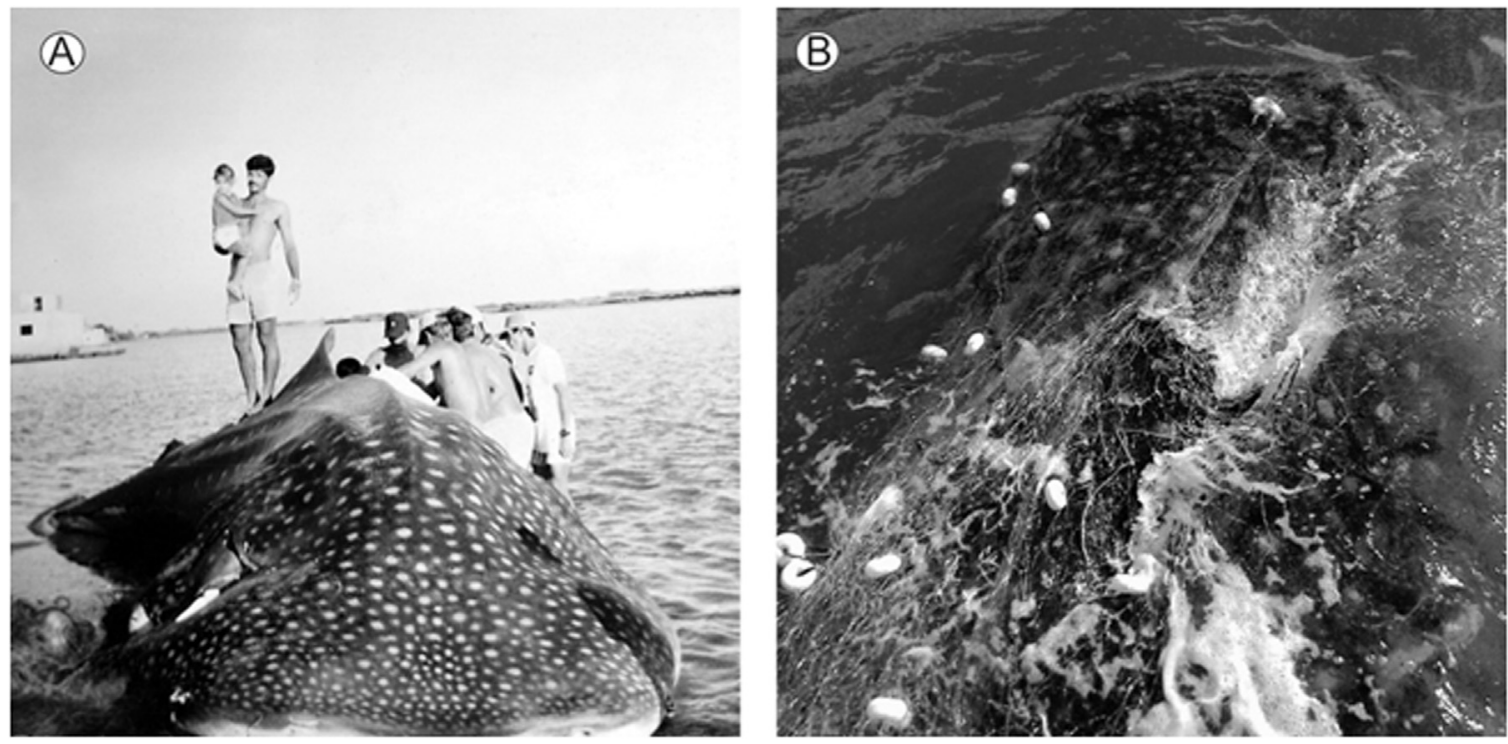

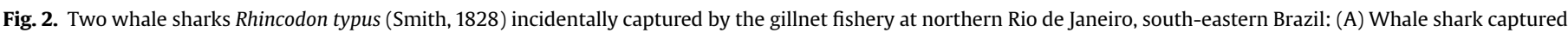
on 02 February 2001; (B) Whale shark captured and released on 19 July 2012 
Table 1

Published and new records of the whale shark Rhincodon typus Smith, 1828 in Rio de Janeiro State, south-eastern Brazilian coast. Table informs records dates, localities, record type and source. Published and new records of the whale shark Rhincodon typus Smith, 1828 in Rio de Janeiro State, south-eastern Brazilian coast. Table informs records dates, localities, record type and source.

\begin{tabular}{|c|c|c|c|}
\hline Date & Locality & Record type & Source \\
\hline February 1983 & Rio de Janeiro & Sighting & [27] \\
\hline 27 March 1984 & Arraial do Cabo & Stranded carcass & {$[20]$} \\
\hline March 1987 & Arraial do Cabo & $\begin{array}{l}\text { Stranded alive and } \\
\text { released }\end{array}$ & Present study \\
\hline November 1991 & Macaé & Sighting & {$[20]$} \\
\hline February 1992 & Rio de Janeiro & Sighting & [20] \\
\hline 21 May 1993 & Arraial do Cabo & Stranded alive and died & [20] \\
\hline 27 May 1993 & Arraial do Cabo & $\begin{array}{l}\text { Stranded alive and } \\
\text { released }\end{array}$ & [27] \\
\hline June 1994 & Rio de Janeiro & Sighting & [27] \\
\hline November 1994 & Rio de Janeiro & Sighting & [27] \\
\hline 18 March 1995 & Angra dos Reis & Sighting & [27] \\
\hline 3 June 1995 & Arraial do Cabo & Stranded carcass & [28] \\
\hline 16 August 1997 & Angra dos Reis & Sighting & [27] \\
\hline 28 August 1998 & Macaé & Stranded carcass & [27] \\
\hline 2 January 2001 & Quissamã & $\begin{array}{l}\text { Incidental capture by } \\
\text { gillnet }\end{array}$ & [27] \\
\hline 2 February 2001 & Carapebus & $\begin{array}{l}\text { Incidental capture by } \\
\text { gillnet }\end{array}$ & Present study \\
\hline April 2005 & Arraial do Cabo & Sighting & [27] \\
\hline 17 December 2011 & Rio de Janeiro & Sighting & Present study \\
\hline 19 July 2012 & Quissamã & $\begin{array}{l}\text { Incidental capture by } \\
\text { gillnet }\end{array}$ & Present study \\
\hline
\end{tabular}

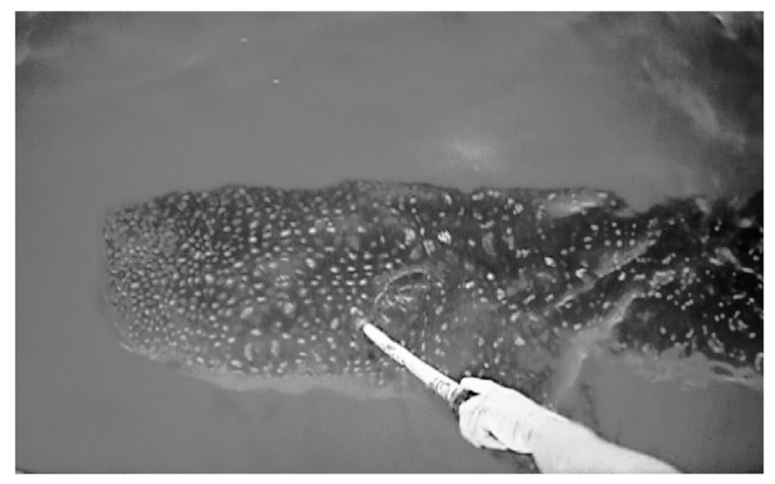

Fig. 3. Whale shark (Rhincodon typus) touched by fisherman with a wooden stick at the Royal Charlotte Oceanic Bank, Bahia State, Brazil, on October 2011. Image credits: Milton dos Anjos.

by local fishermen are not isolated. These participants strongly believe that these types of interactions do not have the potential to harm the animals. Furthermore, most respondents $(n=56 ; 75.7 \%)$ reported that they had seen whale sharks in the region.

The range in total length of the animals sighted varied from two to fourteen meters. Only one fisherman reported an incidental catch of one individual of this species over 30 years ago. All participants reported that, regionally, these sharks are not captured often, mainly due to their size and because the meat is poor in quality.

\section{Discussion}

Some studies have recorded the participation of Brazilian small-scale fishermen in selling shark fins [29-31]. Once in the international shark fin market, this by-product is exported to some countries in Asia, used as display in shark fin soup restaurants and can reach very high values [32]. However, there are no records that whale shark fins are being marketed in Brazil.
An incidental catch of $R$. typus in a gillnet and the commercialization of the specimen was recorded by Faria et al. [33], which took place on January 2009, in Fortaleza, Ceará. In this case, the captain of the vessel was prosecuted by Brazilian environmental authorities (IBAMA), although he claimed ignorance of Instruction No. 5 [34], which prohibited the capture and transport of the species when the incident happened. Given this fact, it appears that environmental awareness interventions targeted at fishermen could clarify the conservation status of $R$. typus in Brazil.

It should be mentioned that the fishing ground near Barra do Furado is located adjacent to Restinga de Jurubatiba National Park. Our records are the first detailed information on incidental captures of $R$. typus with gillnets off the Rio de Janeiro coast, in the South Atlantic Ocean. Fishing activities in northern Rio de Janeiro are fairly well documented (e.g. [35]). Di Beneditto et al. [36] described the incidental capture of small cetaceans from the area, particularly Guiana (Sotalia guianensis) and Franciscanas (Pontoporia blainvillei) dolphins by gillnet fisheries. However, specific information about the small fishing fleet of Barra do Furado is limited.

It is crucial to implement actions in order to reduce incidental capture of whale sharks by artisanal fisheries in Brazil, mainly because most reports are of dead specimens captured incidentally by small-scale fishery nets [20]. A whale shark release, as reported in the present study, was described by Gomes et al. [27], which took place in Arraial do Cabo, Rio de Janeiro, and was an animal that had been caught in a gillnet. Shahid et al. [37] reported the successful release of twelve whale sharks from fishing nets in the Arabian Sea between January 2013 and June 2015. This success was attributed to the previous training the fishermen had in anticipation of incidental captures. In fact, Hsu et al. [12] argue that management regulation would be more effective if there were educational programs for fisherman and the general public about $R$. typus and the importance of its conservation. Recently, the United States implemented a compliance guide, called "Fishing Restrictions related to the Oceanic Whitetip Shark, the Silky Shark and the Whale Shark", to restrict incidental captures of these species on the Central and West coasts of the Pacific Ocean [38]. According to this document, all vessels operating in the country are forced to delay the deployment of seine fishing nets when whale sharks are seen within the fishing area and to take all necessary actions to release any entangled individuals alive.

The movement patterns of whale sharks along the coast of Rio de Janeiro State seem to be associated to local currents, which provide highly productivity waters $[5,39,40]$. However, a considerable number of sightings of $R$. typus were recently reported around the mid-oceanic area of St. Paul's Rocks $\left(0^{\circ} 55^{\prime} \mathrm{N}, 29^{\circ} 20^{\prime} \mathrm{W}\right)$, which is not highly productive $[18,41]$. These studies reported the use of the waters around St. Paul's Rocks as a resting point on their unknown migratory route in the Atlantic. In our review, the majority of $R$. typus records are from the northern part of Rio de Janeiro State $(n=11)$, a region under the influence of an upwelling system. During the spring and summer seasons, greater densities of zooplankton are recorded in the region, as well as large densities of phytoplankton [42,43], but the waters could be considered highly productive throughout the year. According to Table 1 , the records of $R$. typus along coastal Rio de Janeiro do not show defined patterns in response to upwelling periods. Several studies conducted in different areas around the world highlight the relationship between whale shark occurrence patterns and highly productive waters (e.g., [13,44-46]).

Although the RCOB is a region that historically stands out as a productive commercial and recreational fishing zone, there is a considerable gap in scientific studies about this region. This is the first record of a whale shark in the area. On the video, the animal was apparently in ram-feeding position [2], a strategy adopted for 
low prey densities [47]. Indonesian fishermen have similarly reported the presence of whale sharks ram-feeding near their vessels and chasing schools of small fish [48]. According to Stewart [49], some individuals end up injured due to contact with fishing boats during such displays. Whale sharks have also been observed being hand-fed by fishermen [2] and being attracted to the concentration of small fish in local fishermen nets in the Papua Province of Indonesia [49]. In Brazil, Andrades et al. [19] suggested a potential attraction of whale shark to oil platforms, where zooplankton aggregations often occur.

Despite the fact that the fishermen were not conscious about the imminent risk of injuries during the interaction episodes, published reports show that whale sharks often dive away, change direction and demonstrate banking behavior when an interaction occurs during feeding activities [9]. Their reaction varies widely, with some animals showing no signs of stress or aggression [1], while others show defensive behaviors [6]. In addition, Norman [50] suggests that in Ningaloo Marine Park, Australia, a region where there is an ecotourism industry based on swimming close to whale sharks, the average interaction time declined along three consecutive years (19.3 $\mathrm{min}$ in 1995, $14.2 \mathrm{~min}$ in 1996 and $9.5 \mathrm{~min}$ in 1997), which is probably because these fish have become less tolerant of human contact.

In fact, the fishermen reported that all sightings were of solitary animals. This makes the ecological knowledge shared by these fishermen especially relevant, given there are still notable gaps in the scientific knowledge about whale shark ecology when not in feeding aggregations [2].

The reasons the fishermen had for not catching whale sharks (mainly size and poor meat quality), demonstrate they were not aware of the federal law prohibiting the capture of $R$. typus in Brazil.

\section{Conclusion}

The occurrence of whale sharks off the coast of Rio de Janeiro State is well known, and our review of these incidents suggests the species uses highly productive waters along the northern coast of Rio de Janeiro as a feeding ground. Both events of incidental capture of $R$. typus obtained from our non-systematic data collection suggest that this kind of negative interaction may be underestimated. The distribution and migration routes of $R$. typus off the southeastern Brazilian coast should be better studied by systematic surveys and interviews with fishermen, especially to build a hotspot map of the interactions with fisheries.

Based on the mutual curiosity between fishermen and R. typus, as supported by this study and various cases reported in the media, it is reasonable to presume that harassment of this species occurs in different regions of the world. Thus, because science has not accurately predicted the potential implications of these interactions on the species, it is necessary to adopt outreach and awareness programs for fishermen in order to educate them about what to do when sighting whale sharks.

Information of this nature is fundamental to support governmental plans to regulate fishing activities in order to reduce incidental capture and any potential harm derived from harassing whale sharks. Promoting the participation of fishermen in a collaborative monitoring program, may be a good way to better understand the risks involved (on the behavior and ecology of the species) at a reduced cost, particularly for developing countries, such as Brazil.

\section{Conflicting interests}

The authors declare there are no conflicting interests.

\section{Acknowledgments}

We would like to thank Conselho Nacional de Desenvolvimento Científico e Tecnológico (CNPQ) for the fellowship granted to M. Barbosa Filho (M.S.) and Zoology Graduate Program (UESC) for logistical support. The authors are grateful to the municipal authorities of Quissamã and ICMBio, and the Ecology and Natural Resources Postgraduate Program, Universidade Estadual do Norte Fluminense. Special thanks goes to all the fishers who took part in this study. J.F. Moura gratefully acknowledges Coordenação de Aperfeiçoamento de Pessoal de Nível Superior (CAPES) and the Alexander von Humboldt Foundation for financial support (Proc. BEX 0128/14-7).

\section{References}

[1] L.J.V. Compagno, Sharks of the world: an annotated and illustrated catalogue of shark species known to date, vol 2: bullhead, mackerel, and carpet sharks (Heterodontiformes, Lamniformes and Orectolobiformes), FAO Species Cat for Fishery Purp No. 1, Rome, 2001.

[2] D. Rowat, K.S. Brooks, A review of the biology, fisheries and conservation of the whale shark Rhincodon typus, J. Fish. Biol. 8 (2012) 1019-1056, http://dx. doi.org/10.1111/j.1095-8649.2012.03252.x.

[3] J.G. Colman, A review of the biology and ecology of the whale shark, J. Fish. Biol. 51 (1997) 1219-1234, http://dx.doi.org/10.1111/j.1095-8649.1997.tb01138. $\mathrm{x}$.

[4] P.J. Motta, M. Maslanka, R.E. Hueter, R.L. Davis, R. de la Parra, S.L. Mulvany, M. L. Habegger, J.A. Strother, K.R. Mara, J.M. Gardiner, J.P. Tyminski, L.D. Zeigler, Feeding anatomy, filter-feeding rate, and diet of whale sharks Rhincodon typus off the Yucatan Peninsula, Mexico, Zoology 113 (2010) 199-212, http://dx.doi. org/10.1016/j.zool.2009.12.001.

[5] S.A. Eckert, B.S. Stewart, Telemetry and satellite tracking of whale sharks, Rhincodon typus, in the Sea of Cortez, Mexico, and the north Pacific Ocean, Environ. Biol. Fish. 60 (2001) 299-308, http://dx.doi.org/10.1023/ A:1007674716437.

[6] R.A. Martin, A review of behavioural ecology of whale sharks (Rhincodon typus), Fish. Res. 84 (2007) 10-16, http://dx.doi.org/10.1016/j.fishres.2006.11.010.

[7] A.J. Gallagher, N. Hammerschlag, Global shark currency: the distribution, frequency and economic value of shark ecotourism, Curr. Issues Tour. 14 (2011) 797-812, http://dx.doi.org/10.1080/13683500.2011.585227.

[8] R. Mau, Managing for conservation and recreation: the Ningaloo whale shark experience, J. Ecotour. 7 (2008) 213-225, http://dx.doi.org/10.1080/ 14724040802140550.

[9] A.L. Quiros, Tourist compliance to a code of conduct and the resulting effects on whale shark (Rhincodon typus) behavior in Donsol, Philippines, Fish. Res. 84 (2007) 102-108, http://dx.doi.org/10.1016/j.fishres.2006.11.017.

[10] S.J. Pierce, B. Norman, Rhincodon typus. The IUCN Red List of Threatened Species 2016: e.T19488A2365291, 2016 . 〈http://www.iucnredlist.org/details/ 19488/0> (accessed 05.08.16)

[11] A. Capietto, L. Escalle, P. Chavance, L. Dubroca, A.D. Molina, H. Murua, L. Floch, A. Damiano, D. Rowat, B. Merigot, Mortality of marine megafauna induced by fisheries: insights from the whale shark, the world's largest fish, Biol. Conserv. 174 (2014) 147-151, http://dx.doi.org/10.1016/j.biocon.2014.03.024.

[12] H.H. Hsu, S.J. Joung, K.M, Fisheries, management and conservation of the whale shark Rhincodon typus in Taiwan. J. Fish. Biol. 80 (2012) 1595-1607, http://dx.doi.org/10.1111/j.1095-8649.2012.03234.x.

[13] K.V. Akhilesh, C.P.R. Shanis, W.T. White, H. Manjebrayakath, K.K. Bineesh, U. Ganga, E.M. Abdussamad, A. Gopalakrishnan, N.G.K. Pillai, Landings of whale sharks Rhincodon typus; Smith, 1828 in Indian waters since protection in 2001 through the Indian Wildlife (Protection) Act, 1972, Environ. Biol. Fish. 96 (2012) 1-10, http://dx.doi.org/10.1007/s10641-012-0063-9.

[14] M.N.R. Alava, A.A. Yaptinchay, E.R.Z. Dolumbal, R.B. Trono, Fishery and trade of whale sharks and manta rays in the Bohol Sea, Philippines, in: S.L. Fowler, T.M. Reed, F.A. Dipper (Eds.), Elasmobranch Biodiversity, Conservation and Management, Proceedings of the International Seminar and Workshop, Sabah, 2002, pp. 132-148.

[15] E.G. Silas, The whale shark (Rhincodon typus Smith) in Indian coastal waters: is the species endangered or vulnerable? Mar. Fish. Inf. Tech. Ext. Ser. 66 (1986) $1-19$.

[16] E. Vivekanandanm, M.S. Zala, Whale shark fishery off Veraval, Indian J. Fish. 41 (1994) 37-40.

[17] L. McClenachan, A.B. Cooper, N.K. Dulvy, Rethinking trade-driven extinction risk in marine and terrestrial megafauna, Curr. Biol. 26 (2016) 1640-1646, http://dx.doi.org/10.1016/j.cub.2016.05.026.

[18] F.H.V. Hazin, T. Vaske-Júnior, P.G. Oliveira, B.C.L. Macena, F. Carvalho, Occurrences of whale shark (Rhincodon typus Smith, 1828) in the Saint Peter and Saint Paul Archipelago, Brazil, Braz. J. Biol. 68 (2008) 385-389, http://dx.doi. org/10.1590/S1519-69842008000200021.

[19] R. Andrades, H.T. Pinheiro, R.G. Santos, A.S. Martins, P.A.S. Costa, A new record 
of whale shark Rhincodon typus in Brazilian waters: a report of association with Caranx crysos, J. Fish. Biol. 6 (2012) 2092-2094, http://dx.doi.org/10.1111/ j.1095-8649.2012.03460.x.

[20] J.M.R. Soto, W. Nisa-Castro-Neto, Sobre a presença do tubarão-baleia Rhincodon typus Smith, 1829 (Chondrichthyes, Rhincodontidae) na costa brasileira, Biociencias 8 (2000) 137-152.

[21] J.M. Soto, Annotated systematic checklist and bibliography of the coastal and oceanic fauna of Brazil. I - Sharks, Mare Magnum 1 (2001) 51-120.

[22] BRASIL, PORTARIA no 445, de 17 de dezembro de 2014, Ministério do Meio Ambiente. 〈http://www.pescamadora.com.br/pdf/Portaria-MMA-445_2014Lista-Peixes-Ameacados-Extincao.pdf (accessed 22.05.15).

[23] J.L. Valentin, The Cabo Frio Upwelling System, Brazil, in: U. Seeliger, B. Kjerfve (Eds.), Coastal Marine Ecosystem of Latin America, Springer, Berlin, 2001, pp. 97-105, http://dx.doi.org/10.1007/978-3-662-04482-7_8.

[24] G.F. Dutra, G.R. Allen, T. Werner, S.A. McKenna, A Rapid Marine Biodiversity Assessment of the Abrolhos Bank, Bahia, Brazil, the RAP Bulletin of Biological Assessment, Conservation International,, Washington, 2006.

[25] P.A.S. Costa, G. Olavo, A.S. Martins, Áreas de pesca e rendimentos da frota de Linheiros na região central da costa brasileira entre Salvador-BA e o Cabo DE São Tomé-RJ, in: P.A.S. Costa, A.S. Martins, G. Olavo (Eds.), Pesca e potenciais de exploração de recursos vivos na região central da Zona Econômica Exclusiva brasileira, Museu Nacional, Rio de Janeiro, 2005, pp. 57-70.

[26] (MMA, Ministério do Meio Ambiente, Proposição de Unidades de Conservação na Região de Abrolhos. Documento Base, Instituto Chico Mendes de Conservação da Biodiversidade - ICMBio, Brasília), 2012.

[27] U.L. Gomes, C.N. Signorini, O.B.F. Gadig, H.R.S. Santos, Guia Para identificação DE tubarões e raias Do Rio DE Janeiro, Technical Books, Rio DE Janeiro, 2010.

[28] U.L. Gomes, M.C. Lima, C. Paragó, Catálogo das coleções ictiológicas do Departamento de Biologia Animal e Vegetal, Universidade Do Estado Do Rio DE Janeiro UERJ,, Rio DE Janeiro, 1997.

[29] A.F. Amorim, C.A. Arfelli, S. Bacilieri, Shark data from Santos longliners fishery off southern Brazil (1971-2000), Col. Vol. Sci. Pap. ICCAT 54 (2002) 1341-1348.

[30] H.V. Hazin, M.K. Broadhurst, A.F. Amorim, C.A. Arfelli, A. Domingo, Catches of pelagic sharks by subsurface longline fisheries in the South Atlantic Ocean during the Last Century: A Review of Available Data with Emphasis on Uruguay and Brazil, in: M.D. Camhi, E.K. Pikitch, E.A. Babcock (Eds.), Sharks of the Open Ocean: Biology, Fisheries and Conservation, Blackwell Publishing, Oxford, 2008, pp. 213-229.

[31] M.F. Pinto, J.S. Mourão, R.R.N. Alves, Ethnotaxonomical considerations and usage of ichthyofauna in a fishing community in Ceará State, Northeast Brazil, J. Ethnobiol. Ethnomed. 9 (2012) 1-11, http://dx.doi.org/10.1186/17464269-9-17.

[32] R.J. Lopes, O ocaso de um predador, Unesp Ciência 35 (2012) 20-26.

[33] V.V. Faria, I.M. Venancio, T.H. Basilio, L.M. Silveira, B. Jucá-Queiroz, O.B. F. Gadig, A.A. Furtado-Neto, Captura Incid. DE Um. tubarão-baleia, Rhincodon typus (Orectolobiformes, Rhincodontidae), na Costa Do Ceará, Nordeste Do Bras., PANAMJAS 4 (2009) 599-604.

[34] MMA, Ministério do Meio Ambiente, 2004. Instrução Normativa No. 5, de 21 de maio de 2004, anexo I. Diário Oficial da União, Brasília. 〈http://www.ibama.
gov.br/category/40?download=1266\%3A05-2004-.p $>$ ((accessed) 22.05.16).

[35] A.P.M. Di Beneditto, Artisanal fishery on the northern coast of Rio de Janeiro, Bioikos 15 (2001) 103-107.

[36] A.P.M. Di Beneditto, R.M.A. Ramos, N.R.W. Lima, Fishing activity in Northern Rio de Janeiro State (Brazil) and its Relation with Small Cetaceans, Braz. Arch. Biol. Technol. 41 (1998) 1-7, http://dx.doi.org/10.1590/ S1516-89131998000300004.

[37] U. Shahid, M.M. Khan, R. Nawaz, Update Shark -Catch. Tuna gillnet Fish. Pak. INDIAN Ocean Tuna Comm. - Iotc-2015-wpeb, 11-46, Olhão, Port. (2015) 11.

[38] (NOAA, National Oceanic and Atmospheric Administration, Compliance Guide - Fishing Restrictions related to the Oceanic Whitetip Shark, the Silky Shark and the Whale Shark. U.S. Department of) Commerce, NOAA Fisheries - Pacific Islands Regional Office 2015.

[39] C.A. Alecrim-Santos, J.V. Andreatta, U.L. Gomes, Sobre a ocorrência de Rhincodon typus Smith, 1829 (Elasmobranchii, Rhincodontidae) em águas brasileiras e aspectos de sua taxonomia, Acta Biol. Leopoldensia 10 (1988) 175-182.

[40] E. Clark, D.R. Nelson, Young whale sharks, Rhincodon typus, feeding on a copepod bloom near La Paz, Mexico, Environ. Biol. Fish. 50 (1997) 63-73, http: //dx.doi.org/10.1023/A:1007312310127.

[41] P. Travassos, F.H.V. Hazin, J.R.A.R. Zagaglia, J. Shoeber, Thermohaline structure around seamounts and islands off North-Eastern Brazil, Arch. Fish. Mar. Res 47 (1999) 211-222.

[42] J.L. Valentin, W.M. Monteiro-Ribas, M.A. Mureb, E. Pessoti, Sur quelques zooplanctontes abondants dans l'upwelling de Cabo Frio (Brésil), J. Plankton Res. 9 (1987) 1195-1216, http://dx.doi.org/10.1093/plankt/9.6.1195.

[43] C. Bassani, A.C.T. Bonecker, S.L.C. Bonecker, C.R. Nogueira, J.M. Reis, L. R. Nascimento, Plâncton do litoral norte do estado do Rio de Janeiro - Análise e síntese do conhecimento, Oecol. Bras. 7 (1999) 99-120.

[44] S.H. Prater, The whale shark (Rhincodon typus Smith) in Indian Coastal waters, J. Bomb. Nat. Hist. Soc. 42 (1941) 255-279.

[45] T. Arnborn, V. Papastravrou, Fish in the association with whale sharks Rhincodon typus near the Galapagos islands, Notic, Galápagos 46 (1988) 13-15.

[46] R.P. Venegas, R. Hueter, J.G. Cano, J. Tyminski, J.G. Remolina, M. Maslanka, A. Ormos, L. Weigt, B. Carlson, A. Dove, An unprecedented aggregation of Whale Sharks, Rhincodon typus, in Mexican Coastal Waters of the Caribbean Sea, PLoS ONE 6 (2011) 1-8, http://dx.doi.org/10.1371/journal.pone.0018994.

[47] J.D. Nelson, S.A. Eckert, Foraging ecology of whale sharks (Rhincodon typus) within Bahía de los Angeles, Baja California Norte, México, Fish. Res. 84 (2007) 47-64, http://dx.doi.org/10.1016/j.fishres.2006.11.013.

[48] N.E. Stacey, J. Karam, M.G. Meekan, S. Pickering, J. Ninef, Prospects Whale Shark Conserv. East. Indones. Bajo Tradit. Ecol. Knowl. Community-Based Monit., Conserv. Soc. 10 (2012) 63-75, http://dx.doi.org/10.4103/09724923.92197.

[49] B.S. Stewart, Workshop and Monitoring Training for Whale Sharks. Cendrawasih Bay National Park, West Papua 2 - 7 May 2011, Hubbs-Sea World, Res. Inst. Tech. Rep. 375, Naribe (2011) 1-27.

[50] B. Norman, Aspects of the biology and ecotourism industry of the whale shark Rhincodon typus in north-western Australia (M. Phil Thesis), Murdoch University,, Western Australia, 1999. 